\title{
STRATEGI PENGEMBANGAN BUDIDAYA RUMPUT LAUT DI PULAU NAIN KABUPATEN MINAHASA UTARA
}

\author{
(Strategy of Seaweed Cultivation Development in Nain Island, North Minahasa)
}

\author{
Loura Pandelaki ${ }^{1}$ \\ ${ }^{1}$ Sekolah Tinggi Informatika Manajemen dan Komputer (STIMIK) Matuari, Manado, Sulawesi Utara.
}

\begin{abstract}
Pengembangan rumput laut di Pulau Nain membutuhkan strategi untuk meningkatkan kembali produksinya. Penelitian ini bertujuan untuk menentukan strategi-strategi dalam pengembangan budidaya rumput laut. Penyusunan strategi menggunakan analisis strategi pengembangan yang terdiri atas: análisis lingkungan, SWOT dan QSPM. Tiga prioritas strategi yang direkomendasikan untuk pengembahgan budidaya rumput laut yakni: Mengefektifkan peran DKP dan lembaga terkait dalam pembinam dan pengembangan SDM; peningkatan sumber permodalan usaha; dan pengadaan pola kerjasama kemitraan pasar.

Kata kunci: strategi pengembangan, rumput laut, produksi, SWOT, QSPM, analisis lingkungan.
\end{abstract}

The development of seaweed cultivation in the Nain Island requires appropriate strategies to reenhance its production. The objectives of this study is to determine strategies in developing the seaweed cultivation. Development strategy analysis was used as steps to determine strattegy for the development of the seaweed cultivation. Analysis of the development strategy consists of: environmental analysis, SWOT analysis and QSPM. The three priority strategies for development of seaweed cultivation are as follows: Maximizing the role of DKP and related institutions in coaching and developing human resource; increasing venture capital sources; dan procurement $\sigma$ f market partnership patterns.

Keywords: development strategy, seaweed, production, SWOT, QSPM, environmental analysis.

\section{PENDAHULUAN}

Rumput laut merupakan salah satu produk unggulan dalam kebijakan pemerintah yang akan menjadikan Indonesia sebaga penghasil produk perikanan laut terbesar đi- dunia pada tahun 2015. Keoptimisan ini dídasarkan pada peningkatan produksi rumput laut Indonesia. Tahun 2009 produksi rumput-laut sebesar 2,7 juta ton, pada tahun 2010 meningkat menjadi 3,1 juta ton, selanjutnya pada tahun 2011 naik menjadi 4,3 juta ton, Target produksi rumput laut untuk tahun 2012 adalah sebesar 5,1 juta ton ( $\mathrm{Si}$ regar dan Mutaqin 2011; KKP 2012).

- Pencapaian target produk rumput laut ditenfukan oleh banyak faktor dan strategi. Anggadiredja (2007) menyatakan bahwa keberlanjutan agribisnis rumput laut ditentukan oleh: jaminan kualitas dan kontinuitas produksi (sistem produksi), pasar (jejaring), modal usaha, dan jaminan untuk berusaha (regulasi). Sedangkan untuk strategi pengembangannya, menurut Keppel (2008), dapat ditempuh melalui pemetaan dan penataan kawasan budidaya, pengembangan sistem usaha dalam kawasan, penguatan kelembagaan dan pemberdayaan pembudidaya,
- penciptaan iklim usaha yang kondusif, pengembangan sarana dan prasarana, serta pengembangan mutu dan nilai tambah.

Kabupaten Minahasa Utara memiliki luasan yang sangat berpotensi untuk pengembangan budidaya rumput laut. Data yang ada menunjukkan potensi areal budidaya rumput laut di Kabupaten Minahasa Utara seluas 3.782 hektar. Pulau Nain sebagai salah satu pulau di Kabupaten Minahasa Utara, memiliki potensi areal budidaya rumput laut seluas 2.723 hektar. Sebagian besar penduduknya $( \pm 90 \%)$ Bermata pencaharian sebagai pembudidaya rumput laut (Mondoringin 2005).

Kegiatan budidaya rumput laut di perairan Pulau Nain dimulai sekitar tahun 1989, dan selanjutnya berkembang sebagai mata pencaharian utama pada sekitar tahun 1995. Puncak produksi rumput laut di terjadi pada tahun 1996 -2000 yaitu sebanyak 350-400 ton per tahun. Kemudian produksinya menurun mulai akhir tahun 2000 (Gerung et al., 2008). Data 2010 dari Dinas Kelautan dan Perikanan Kabupaten Minahasa Utara (DKP Minut) menunjukkan bahwa produksi rumput laut dari Pulau Nain pada tahun 2009 hanya 22 ton per tahun. 
Dari beberapa laporan hasil penelitian, masalah penurunan produksi rumput laut disebabkan oleh suatu sistem yang sangat kompleks, berupa hubungan antar faktor biologi atau faktor interaksi bio-fisik dalam ekosistem. Produksi rumput laut di Pulau Nain yang menurun diduga disebabkan oleh pemakaian bibit yang berulang selama lebih dari 20 tahun sehingga bibit tersebut memiliki mutu yang rendah karena telah membawa bibit penyakit atau daya tahan terhadap penyakit sudah berkurang (Gerung et al., 2008; Wantasen dan Tamrin, 2012). Upaya peningkatan kembali produksi rumput laut di Minahasa Utara, khususnya di Pulau Nain, memerlukan strategi berupa suatu kebijakan dalam pengelolaannya.

Strategi adalah suatu seni menggunakan kecakapan dan sumberdaya suatu organisasi untuk mencapai sasarannya melalui hubungan efektif dengan lingkungan dalam kondisi yang paling menguntungkan (Salusu 1996). Rangkuti (2008) menyatakan bahwa strategi merupakan perencanaan hidup yang komprehensif yang menjelaskan bagaimana perusahaan mencapai semua tujuan yang telah ditetapkan berdasarkan misi yang telah ditentukan sebelumnya.

Berdasarkan hal-hal tersebut maka penelitian ini ditujukan untuk menentukan strategi-strategi dalam pengembangan budidaya rumput laut di Pulau Nain Kecamatan Wori paten Minahasa Utara.

\section{METODE PENELITIAY}

\section{Sumber Data}

Data primer dikumpulkăn melalui survei di lapangan dan wawanearaterhadap responden dengan menggunakan kuisioner. Responden berasal dari kelompok pembudidaya, pedagang/pengumpul, pimpinan DKP Minut, akademisi, praktisi dar pengusaha. Kelompok pembudidaya rumpat laut dipilih 10 kelompok secara acak dari 64 kelompok; Pedagang/pengumpul dipilih sebanyak 4 orang secara acak dari 15 pengumpul. Data sekunder diperoleh dari hasilhasil penelitian sebelumnya, data desa, DKP Sulut, DKP Minut, dan Badan Pemberdayaan Masyarakat-Pemerintah Desa (BPM-PD) Minahasa Utara.

\section{Analisis Data}

Analisis deskripsi didasarkan pada fakta-fakta, kemudian dikumpulkan menjadi sebuah informasi yang digunakan untuk analisis le- bih lanjut dan penentuan strategi pengembangan budidaya rumput laut di masa mendatang.

Analisis strategi berupa langkah-langkah untuk menyusun strategi pengembangan budidaya rumput laut di Pulau Nain, yakni:

a. Analisis lingkungan.

Mengidentifikasi faktor lingkungan internal dan eksternal yang berpengaruh terhadap pengembangan budidaya rumput laut di Pulau Nain. Hasilnya berupa unsur kekuatan dan kelemahan sebagai faktor strategis internal, serta unsur peluang dan ancaman sebagai faktor strategis eksternat. Datá ditabulasikan dalam matriks IFE (Internal Factor Evaluation) dan EFE (External Factor Evaluation).

Skor bobot total tertinggi yang mungkin dicapai untuk sebuah organisasi adalah 4,0 dan skor bobot terendah adalah 1,0. Rata-rata skor bobot total adalah 2,5. Skor bobot total sebesar 4,0\% mengindikasikan bahwa sebuah opganisasi secara efektif mampu menarik keuntungan dari peluang yang ada dan meminimalkan pengaruh negatif potensial - dafi athcaman eksternal. Skor total sebesar 1,0 menandakan bahwa strategi perusahaan tidak mampu memanfaatkan peluang yang ada atau menghindari ancaman yang ada.

\section{b. Analisis SWOT}

Metode strategi yang sering digunakan adalah analisis SWOT (Strength, Opportunities, Weaknesses, Threats), di mana analisis bisa dianggap sebagai metoda yang paling dasar, berguna untuk melihat suatu topik atau permasalahan dari empat sisi yang berbeda. Hasil analisis biasanya adalah arahan atau rekomendasi untuk mempertahankan kekuatan dan menambah keuntungan dari peluang yang ada, sambil mengurangi kekurangan dan menghindari ancaman. David (2007) menyatakan bahwa analisis SWOT adalah sebuah alat pencocokan penting yang membantu para manajer mengembangkan empat jenis strategi yaitu: SO (kekuatan-peluang), WO (kelemahan-peluang), ST (kekuatan-ancaman), dan WT (kelemahan-ancaman).

Analisis SWOT menggabungkan berbagai faktor kekuatan, kelemahan, peluang dan ancaman yang ada. Hasilnya dapat memberikan sejumlah solusi yang dapat digunakan untuk pengembangan budidaya rumput laut di Pulau Nain. 
c. Analisis QSPM

Analisis QSPM (Quantitative Strategis Planning Matrix) adalah analisis yang digunakan untuk menentukan daya tarik relatif dari berbagai strategi yang didasarkan sampai seberapa jauh faktor-faktor keberhasilan kritis internal dan eksternal dimanfaatkan atau ditingkatkan. David (2007) membuat beberapa langkah untuk mengembangkan QSPM yaitu: Membuat daftar internal dan eksternal dari matriks IFE dan EFE; Memberi bobot pada faktor internal dan eksternal; Memeriksa matriksmatriks pencocokkan dan mengenali strategistrategi alternatif yang dipertimbangkan organisasi untuk diterapkan; Menentukan Total Attractiviness Score (TAS) yang didefinisikan sebagai angka yang menunjukkan daya tarik relatif di setiap strategi pada suatu rangkaian alternatif tertentu dengan mempertimbangkan faktor tertentu. Kisaran TAS yaitu: $1=$ tidak menarik; 2= agak menarik; 3= wajar menarik; dan 4= sangat menarik. Total TAS mengungkapkan strategi yang paling menarik dalam setiap rangkaian alternatif.

\section{HASIL DAN PEMBAHASAN}

Faktor Lingkungan Internal dan Eksternal

Tabel 1. Matriks SWOT

\begin{tabular}{|c|c|c|}
\hline & $\begin{array}{l}\text { S=Strengths } \\
\text { (kekuatan) } \\
\text { Faktor-faktor } \\
\text { kekuatan internal }\end{array}$ & $\begin{array}{l}\text { W=Weaknesses } \\
\text { (Kelemahain) } \\
\text { Faktor-faktor } \\
\text { kelemahan } \\
\text { internal }\end{array}$ \\
\hline $\begin{array}{l}\text { O=Opportunities } \\
\text { (Peluang) } \\
\text { Faktor-faktor } \\
\text { peluang eksternal }\end{array}$ & $\begin{array}{l}\text { Strategi S-O } \\
\text { Menyusun strategi } \\
\text { dengan } \\
\text { menggunakan } \\
\text { kekuatan internal } \\
\text { untuk memperoleh } \\
\text { profity dan peluang } \\
\text { yang ada }\end{array}$ & $\begin{array}{l}\text { Strategi W-O } \\
\text { Menyusun } \\
\text { strategi untuk } \\
\text { memperoleh } \\
\text { keuntungan dari } \\
\text { peluang yang ada } \\
\text { dalam mengatasi } \\
\text { kelemahan }\end{array}$ \\
\hline $\begin{array}{l}\text { T=Threats } \\
\text { (Ancaman) } \\
\text { Faktor-faktor } \\
\text { ancaman eksternal }\end{array}$ & $\begin{array}{l}\text { Strategi S-T } \\
\text { Menyusun strategi } \\
\text { dengan } \\
\text { memanfaatkan } \\
\text { kekuatan yang ada } \\
\text { untuk menghindari } \\
\text { ancaman }\end{array}$ & $\begin{array}{l}\text { Strategi W-T } \\
\text { Menyusun } \\
\text { strategi dengan } \\
\text { cara } \\
\text { meminimalkan } \\
\text { kelemahan dan } \\
\text { menghindari } \\
\text { ancaman }\end{array}$ \\
\hline
\end{tabular}

Faktor-faktor lingkungan internal yang dimiliki oleh Pulau Nain dalam pengembangan budidaya rumput laut meliputi kekuatan dan kelemahan. Faktor penentu internal menggunakan matriks IFE untuk memperoleh bobot, peringkat dan skor terbobot. Hasil analisis matriks IFE se- perti pada Tabel 1, dimana total skor terbobot sebesar 2,25. Total skor tersebut berarti secara internal budidaya rumput laut di Pulau Nain lemah dalam memanfaatkan kekuatan dan mengatasi kelemahan yang ada.

Tabel 2. Hasil Analisis Matriks Internal Factor Evaluation (IFE)

\begin{tabular}{|c|c|c|c|}
\hline Faktor Internal & \multirow[t]{2}{*}{ Bobot } & \multirow{2}{*}{ Peringkat } & \multirow{2}{*}{$\begin{array}{c}\text { Skor } \\
\text { Terbobot }\end{array}$} \\
\hline Kekuatan (Strengths) & & & \\
\hline $\begin{array}{l}\text { 1. Tersedianya areal budi } \\
\text { daya yang luas }\end{array}$ & 0,130 & 4 & \\
\hline 2. Tenaga kerja tersedia & 0,109 & 3 & \\
\hline $\begin{array}{l}\text { 3. Teknologi budi daya } \\
\text { sederhana dan murah }\end{array}$ & 0,110 & & 0,440 \\
\hline $\begin{array}{l}\text { 4. Periode pemeliharaan } \\
\text { singkat }\end{array}$ & 0,096 & & 0,288 \\
\hline Total Skor Terbobot & & & 1,575 \\
\hline Kelemahan (Weaknesses) & & & \\
\hline $\begin{array}{l}\text { 1. Adanya monopoli } \\
\text { dagang }\end{array}$ & & 1 & 0,141 \\
\hline $\begin{array}{l}\text { 2. Kurangnya jaminan utk } \\
\text { pinjaman modal }\end{array}$ & & 1 & 0,153 \\
\hline $\begin{array}{l}\text { 3. Rentan serangan hama } \\
\text { dan penyakit }\end{array}$ & 0,141 & 1 & 0,141 \\
\hline $\begin{array}{l}\text { 4. Kualitas dan kwântitas } \\
\text { bibit tdk mendukung }\end{array}$ & 0,120 & 2 & 0,240 \\
\hline Total Skor Terbobot & & & 0,675 \\
\hline Total Ay & 1,000 & & 2,250 \\
\hline
\end{tabular}

Faktor-faktor lingkungan eksternal meliputi peluang dan ancaman yang dimiliki oleh Pulau Nain dalam pengembangan budidaya rumput laut. Hasil analisis matriks EFE dalam pengembangan budidaya rumput laut di Pulau Nain dapat di lihat pada Tabel 2. Hasil evaluasi faktor eksternal dengan menggunakan matriks EFE, diperoleh total skor terbobot 2,963 yang berada di atas rata-rata (titik tengah) 2,5. Hal ini menunjukkan bahwa budidaya rumput laut di Pulau Nain, mampu memanfaatkan peluang yang ada dan menghindari ancaman yang muncul.

\section{Perumusan Strategi Pengembangan Budidaya Rumput Laut di Pulau Nain \\ Perumusan sepuluh strategi pengem-} bangan budidaya rumput laut di Pulau Nain dilakukan dengan menggunakan matriks SWOT (Tabel 3).

\section{Strategi Strength-Opportunities (S-O)}

Kombinasi antara variabel kekuatan S1, $\mathrm{S} 2, \mathrm{~S} 3$, dan S4 dengan variabel peluang O1, O2, dan $\mathrm{O} 3$ menghasilkan strategi memperluas areal budidaya. Perluasan areal budidaya dilakukan dalam rangka meningkatkan pemanfaatan potensi areal. Perluasan areal dengan melakukan pembinaan dan pendampingan secara intensif untuk me- 
micu animo masyarakat dalam kegiatan usaha budidaya.

Tabel 3. Hasil Analisis Matriks Eksternal Factor Evaluation (EFE)

\begin{tabular}{lccc}
\hline \multicolumn{1}{c}{ Faktor Eksternal } & Bobot & $\begin{array}{c}\text { Pering- } \\
\text { kat }\end{array}$ & $\begin{array}{c}\text { Skor } \\
\text { Terbobot }\end{array}$ \\
\cline { 1 - 2 } Peluang (Opportunities) & 0,134 & 3 & 0,402 \\
$\begin{array}{l}\text { 1. Potensi pasar ekspor } \\
\text { 2. Produk unggulan program } \\
\text { pemerintah }\end{array}$ & 0,137 & 4 & 0,548 \\
$\begin{array}{l}\text { 3. Keberadaan institusi } \\
\text { pendukung }\end{array}$ & 0,121 & 2 & 0,242 \\
$\begin{array}{l}\text { 4. Adanya lembaga keuangan } \\
\text { sebagai penyedia modal }\end{array}$ & 0,154 & 4 & 0,616 \\
\hline Total Skor Terbobot & & & $\mathbf{1 , 8 0 8}$ \\
\hline$\quad$ Ancaman (Threats) & 0,104 & 2 & 0,208 \\
\hline $\begin{array}{l}\text { 1. Ancaman perubahan iklim } \\
\text { global }\end{array}$ & 0,125 & 3 & 0,375 \\
$\begin{array}{l}\text { 2. Hilangnya generasi } \\
\text { pembudi daya rumput laut }\end{array}$ & 0,122 & 3 & 0,366 \\
$\begin{array}{l}\text { 3. Konflik pemanfaatan zona } \\
\text { perairan }\end{array}$ & 0,103 & 2 & 0,206 \\
$\begin{array}{l}\text { 4. Penekanan kuota dan } \\
\text { kontinuitas ekspor }\end{array}$ & & & $\mathbf{1 , 1 5 5}$ \\
\hline Total Skor Terbobot & $\mathbf{1 , 0 0 0}$ & & $\mathbf{2 , 9 6 3}$ \\
\hline Total & &
\end{tabular}

Kombinasi antara variabel kekuatan S1, S2, S3, dan S4 dengan variabel peluang O3 menghasilkan strategi pendampingan teknis dan non teknis kepada pembudidaya. Rendahnya pendidikan dan kurangnya akses pada informasi akibat tidak adanya sarana menjadi penyebab dari rendahnya posisi sosial petani rumput laut. Sad lah satu sarana yang dibutuhkan adalah pendampingan yang dapat dilakukan oleh instânsi terkait. Strategi yang dapat diterapkan yåitu program pendampingan sosial dan pembentukan kelompok sosial.

\section{Strategi Weaknesses-Opportunities $(W-O)$}

Kombinasi antara variabel kelemahan W1 dan W2 dengan yartabel peluang $\mathrm{O} 1$ dan $\mathrm{O} 4$ menghasilkan strategimeningkatkan sumber permodalan usaha. Rendahnya akses pembudidaya terhadap aset finansial untuk modal kerja merupakan kenda a klasik pengembangan sistem produksi. Strateg yang dapat diterapkan yaitu adanya sosialisasi bantuan permodalan usaha.

Kombinasi antara variabel kelemahan W3 dan W4 dengan variabel peluang $\mathrm{O} 2$ dan $\mathrm{O} 3$ menghasilkan strategi mengefektifkan peran DKP dan lembaga terkait dalam pembinaan dan pengembangan sumberdaya manusia. Strategi yang dapat diterapkan yaitu pelatihan bagi pembudidaya, dan partisipasi aktif di kegiatan perikanan.

Kombinasi antara variabel kelemahan W3 dan W4 dengan variabel peluang O3 menghasilkan strategi penetapan kalender musim tanam. Pene- tapan musim tanam adalah untuk menetapkan waktu penanaman yang akan memberikan pertumbuhan yang baik bagi rumput laut. Budidaya rumput laut yang mengacu pada kalender musim tanam akan menghindari kerugian pembudidaya pada waktu kondisi lingkungan yang tidak mendukung.

\section{Strategi Strength-Threats (S-T)}

Kombinasi antara variabel kekuatan S1, S2, S3, dan S4 dengan variabel ancaman T1dan T3 menghasilkan strategi penyuluhan dan pelatikan pasca panen. Dari aspek ini, strategí lang dapat diterapkan yaitu mengadakan penyulthan dan pelatihan, serta pengadaan Terminal Informasi.

Kombinasi antara variabel kekuatan S1 dan S2 dengan variabel ancaman Tl dan T3 menghasilkan strategi pemintakan kesesuaian areal. Strategi yang dapat diterapkan yaitu: pembuatan rencana detail tata ruant kawasan yang dibuat untuk menjamin kéberłan̆gsungan usaha budidaya rumput laut diPulau Nain dan mencegah konflik pemanfaatan ruang di kawasan tersebut yang secara potensial rawan konflik, dan penertiban ijin usaha budídaya rumput laut di Pulau Nain.

\section{Strategi Weaknesses-Threats $(W-T)$}

Kombinasi antara variabel kelemahan W1 dan W2 dengan variabel ancaman T4 menghasilkan strategi pengadaan pola kerjasama kemitraan pasar. Strategi yang dapat diterapkan yaitu: kelembagaan organisasi usaha kelompok budidaya, dan membangun kemitraan usaha antara petani rumput laut dengan pengusaha dengan pola inti rakyat, serta investasi pembuatan pabrik pengolahan, menggandeng kementerian perdagangan untuk dapat memfasilitasi pemanfaatan gudang yang dimiliki swasta, dan ikut serta melakukan intervensi harga rumput laut sehingga tidak mengalami fluktuasi harga.

Kombinasi antara variabel kelemahan W3 dan W4 dengan variabel ancaman T2 dan T4 menghasilkan strategi melakukan penggantian bibit baru. Penggantian bibit rumput laut lama dengan bibit rumput laut baru yang tahan terhadap hama penyakit dan pertumbuhannya cepat. Aspek ini mempunyai dua strategi yaitu pengadaan kebun bibit dan kebun percontohan.

Kombinasi antara variabel kelemahan W3 dan W4 dengan variabel ancaman T3 menghasilkan strategi penataan pemukiman penduduk. Limbah rumah tangga berupa deterjen, plastik, dan minyak sangat mempengaruhi pertumbuhan rumput laut, bahkan bisa mematikannya. 


\section{Prioritas Strategi Pengembangan Budidaya Rumput Laut di Pulau Nain}

Berdasarkan analisis SWOT, diperoleh sepuluh strategi pengembangan budidaya rumput laut di Pulau Nain yang memiliki keterkaitan satu sama lain. Kesepuluh strategi tersebut dapat dilakukan secara bersama-sama apabila sumberdaya yang dimiliki memungkinkan untuk itu. Namun bila ada keterbatasan dana dalam pelaksanaan strategi tersebut secara bersamaan, maka dilakukan pemilihan strategi berdasarkan prioritas. Penentuan strategi dilakukan dengan metode analisis QSPM yaitu dengan melakukan pemilihan nilai Attractiviness Score (daya tarik) relatif dari semua strategi. Penentuan Strategi tersebut dapat dilihat pada Tabel 4 dan perhitungan TAS menghasilkan prioritas pada Tabel 5 .

\section{KESIMPULAN}

Tiga prioritas utama strategi pengembangan budidaya rumput laut di Pulau Nain yaitu: Mengefektifkan peran Dinas Kelautan dan Perikanan, serta lembaga terkait dalam pembinaan dan pengembangan sumberdaya manusia; Peningkatan sumber permodalan usaha, Pengadaan pola kerja sama kemitraan pasar.

Tabel 4. Matriks SWOT Strategi Pengembangan Budi Daya Rumput Laut Pulau Nain

\section{$S=$ Strengths (kekuatan)}

1. Tersedianya areal budi daya yang luas

2. Tenaga kerja tersedia

3. Teknologi budi daya sederhana dan murah

4. Periode pemeliharaan singkat

$W=$ Weaknesses (Kelemahan)

1. Adanyâ monopali pasar

2. Kurangnya jaminan untuk pinjaman modal

3. Rentan serangan hama \&penyakit

4. Kuelitas dan kuantitas bibit tidak mendukung

O=Opportunities (Peluang)

1. Potensi pasar ekspor

2. Produk unggulan program pemerintah

3. Keberadaan institusi pendukung

4. Adanya lembaga keuangan sebagai penyedia modal

T=Threaths (Ancaman)

1. Ancaman perubahan iklim global

2. Hilangnya generasi pembudi daya rumput laut

3. Konflik pemanfaatan zona perairan

4. Penekanan kuota dan kontinuitas ekspor

\section{Strategi S-O}

1. Memperluas areal budi daya ( $\mathrm{S} 1, \mathrm{~S} 2$. S3, S4, O1, O2, O4)

2. Pendampingan teknis \& nơn tekn kepada pembudi daya (\$1, \$2, S3, S4, O3)

Strategi S-T
1. Penyuluhan \& pelatihan pasca panen
(S1, S2, S3, S4, T2, T4)

2. Pemintakan kesesuaian areal (S1, S2,

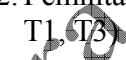

\section{trategi W-O}

1. Peningkatan sumber permodalan usaha(W1, W2, O1, O4)

2. Mengefektifkan peran DKP \& lembaga terkait dalam pembinaan $\&$ pengembangan SDM (W3, W4, O2, O3)

3. Penetapan kalender musim tanam (W3, W4, 03)

\section{Strategi W-T}

1. Pengadaan pola kerjasama kemitraan pasar (W1, W2, T4)

2. Melakukan penggantian bibit baru (W3, $\mathrm{W} 4, \mathrm{~T} 1, \mathrm{~T} 2, \mathrm{~T} 4)$

3. Penataan pemukiman penduduk (W3, T3)

Tabel 5. Hasil analisis Quantitative Strategis Planning Matrix(QSPM)

\begin{tabular}{rlcc}
\hline No & Strategi-strategi pengegmbangan budi daya rumput laut & TAS & Prioritas \\
\hline 1. & Mengefektifkan peranDKP \& lembaga terkait dalam pembinaan \& pengembangan SDM & 6,841 & I \\
2. & Peningkatan sumber permodalan usaha & 6,676 & II \\
3. & Pengadaan polakerjasama kemitraan pasar & 6,312 & III \\
4. & Pendampingan teknis \& non teknis kepada pembudi daya & 6,302 & IV \\
5. Penetapankalender musim tanam & 6,107 & V \\
6. Penyulthan \& pelatihan pasca panen & 5,907 & VI \\
7. Melakukan penggantian bibit baru & 5,844 & VII \\
8. Memperluas areal budi daya & 5,832 & VIII \\
t9. Penataan pemukiman penduduk & 5,775 & IX \\
10. Pemintakan kesesuaian areal & 5,737 & X \\
\hline
\end{tabular}

\section{DAFTAR PUSTAKA}

Anggadiredja JT. 2007. Prospek Pasar Rumput Laut Indonesia di Pasar Global. Lokakarya Implementasi Program Berkelanjutan Sulawesi Selatan Menuju Sentra Rumput Laut Dunia. Makalah. Makasar, 7 Mei 2007.

David FR. 2007. Manajemen Strategis. Edisi kesembilan. Terjemahan. PT. Indeks Kelompok Gramedia. Jakarta.

Gerung G, Soeroto B, dan Ngangi ELA. 2008. Study on The Environment and Trials Cultivation of Kappaphy- cus and Eucheuma in Nain Island, Indonesia. IFC PENSA-World Bank. Manado.

Keppel CR. 2008. Prospek Pengembangan Sumberdaya Rumput Laut di Sulawesi Utara. Makalah dalam Temu Usaha Rumput Laut. Dinas Perikanan dan Kelautan Provinsi Sulawesi Utara. Manado.

[KKP] Kementerian Kelautan dan Perikanan. 2012. Target 5,1 Juta Ton Produksi Rumput Laut. www. tribunnews.com/2012/05/14/kkp-target-51-juta-tonproduksi-rumput-laut. [diunduh 3 Juli 2012]. 
Mondoringin LLJJ. 2005. Kajian Ekologi-Ekonomi Usaha Budidaya Rumput Laut di Kawasan Terumbu Karang Pulau Nain Sulawesi Utara. Tesis. IPB. Bogor.

Rangkuti F. 2008. Analisis SWOT Teknik Membedah Kasus Bisnis. PT. Gramedia Pustaka Utama. Jakarta.

Salusu J. 1996. Pengambilan Keputusan Strategik untuk Organisasi Publik dan Organisasi Nonprofit. PT. Gramedia Widiasarana Indonesia. Jakarta.
Siregar S dan Mutaqin Z. 2011. Produksi Rumput Laut Nasional di Atas Target. Indonesia finance today, Fisheries \& Farming. http://www.indonesiafinancetoday. com.

Wantasen AS dan Tamrin, 2012. Analisis Kelayakan Lokasi Budidaya Rumput Laut di Perairan Teluk Dodinga Kabupaten Halmahera Barat. Jurnal Perikanan dan Kelautan Tropis 8(1): 23-27.

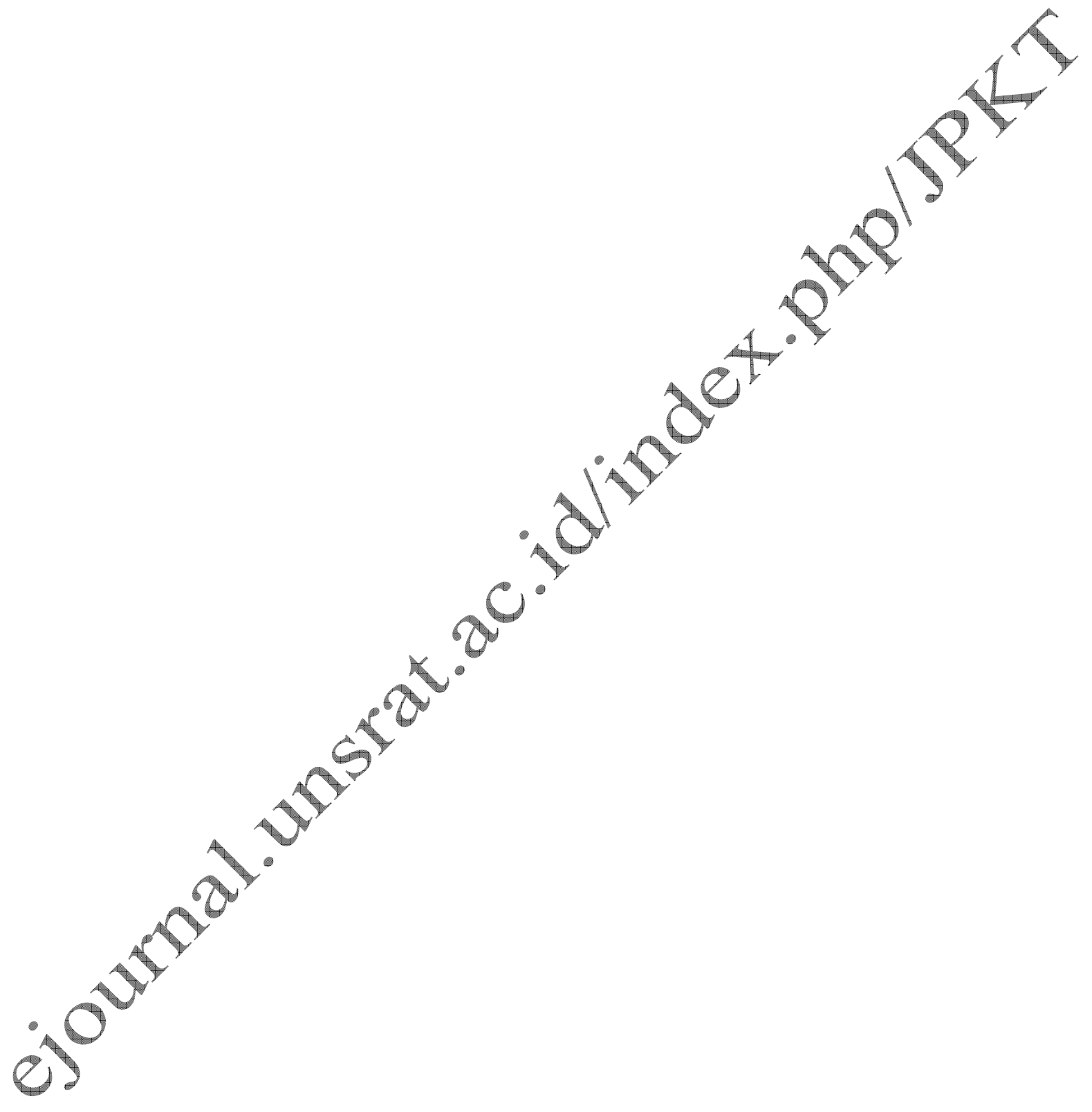

